\title{
The Role of Needs Analysis in English for Specific Purposes
}

\author{
Gusti Astika \\ Universitas Kristen Satya Wacana \\ Salatiga
}

\begin{abstract}
This article discusses the role of needs analysis in ESP. Teaching ESP should not be considered as a different kind of teaching the language but rather as an approach as it is also based on the commonly held belief of teaching language for communicative purposes. The problems that ESP teachers have are similar to those of teachers of English for general purposes although there are some additional problems that may lie beyond methods and pedagogy especially those related to non-linguistic matters. Students' needs are discussed from different angles and the theoretical basis of needs analysis is derived from the ideas of communicative competence proposed by Hymes (1972) and Canale and Swain (1980). Different approaches to needs analysis and its importance are also discussed. Finally, a model of framework for needs analysis as a basis for syllabus design is presented.
\end{abstract}

Key Words: needs analysis, ESP

The continuous advancement of commerce and technology has created the need for students and professionals to master the language of commerce and technology not only for academic purposes but also for occupational purposes. The role of English in commerce and technology has been widely recognized and English courses which cater for this need have been and will continue to play a significant role in the development of commerce and technology. Unlike English courses for general purposes, English for specific purposes is different in the way the course is designed. 


\section{ESP AND ITS PROBLEMS}

The teaching of ESP is, in many ways similar to the teaching of English in general although there are features that are typical in different specialized subjects and that ESP should be recognized as an approach (Hutchinson \& Waters (1987), Crocker (1981), McDonough (1984). According to Hutchinson and Waters (1987), the approach to ESP should be based on the learner's needs in their respective specialized subjects. ESP teaching should be based on the principles of effective learning and teaching language for general purposes. Hutchinson and Waters (1987) further state that in the past, the teaching of ESP was primarly concerned with the linguistic aspects of the language. Now, it has shifted towards developing communication skills and learning is very much directed by specific learner's needs for mastering the language (pp. 18-19). Hutchinson and Water's view of ESP points to the importance and roles of learners both in the design of the course and its implementation in the teaching and learning processes.

Crocker (1981) also recognizes that ESP courses are similar to language instruction in general which puts more emphasis on language use. The obvious difference is in the focus of interest. While English for general purposes emphasizes language proficiency, ESP courses emphasize "something outside of the language through the medium of language" (p.8). This statement views language mastery as a necessary prerequisite skill that learners must have in order to function well in their future workplace. Unlike English courses in general, an ESP course is a means not an end in itself. Crocker (1981) is also of the opinion that ESP should be regarded as an approach to language teaching (p.8)

McDonough (1984) states that although the interest and development of ESP has been very rapid since 1960 s, the ESP teaching should not be recognized as a separate development which is very much different from language teaching in general. ESP, according to McDonough (1984), should be taken as an instructional activity which has its own emphases and range of activities which are not totally different from other areas of language teaching.

Swales (1980) describes his experience in ESP programming in the third world. He states that flexibility in the program design and implementation are important because there are constraints at institutional and socio-cultural levels. Among others, he points to the fact that ESP program is a non-degree program, and hence, it receives low status. This results in inadequate representation within the institution and administrative constraints. Individual status of the ESP teachers is also low because they do not produce graduates with degree levels. Programs and activities are often inappropriate to the context of local cultures and students study and learning habits because program assumptions and practices are imported from the Western world. Swales (1980) proposes that to minimize the constraints, collaborative efforts should be made between ESP teachers, subject teachers and administrators to make necessary modifications towards the desired goals. In this respect, Swales also points out to the need for including the learners' factors especially those related to their study habits and learning strategies. As he puts it,

"... it is very important for a course designer to know not only what his students can do and need to do but also to know what they would be willing to do or could be persuaded to do within the confines of their particular educational environment" (p.68)

In Indonesia, the demand of English language teaching has been increasing both in private sectors and in formal institutions such as those in state and private universities. This demand has been generated by advances in commerce and industry which require people to have adequate command of the language both spoken and written. In spite of the increasing demand for English language teaching, this situation has not invoked sufficient research in ESP, especially the needs of various groups of learners or people who need to have sufficient command in English. The need to address the ESP issue is further necessitated by the fact that the result of English language teaching at the secondary level has not been very encouraging despite six years' study of English. At the tertiary level, complaints from university teachers and employers show that skills in English such as writing reports, reading scientific books, taking minutes or taking part in conversations or meetings (note that these are perceived problems that need supports from research). Another type of evidence that needs to be searched is whether studies or research on the need to use English at the national level, has been done. This study would provide some justification to the analysis of present condition of ESP in Indonesia.

In general, ESP teachers face similar problems like those faced by teachers of English for general purposes such learner factors and methodology. Abbot (1978) points out that ESP teachers will have to face three kinds of problems; materials writing, student motivation, and responsibility of content. Materials have to be 
designed and produced if the existing materials do not match the students' needs and expectations. If materials can be provided, the student motivation has to be taken care of because they may find the materials boring. The teacher will have to reconcile his knowledge of specific subject with the level of knowledge assumed by the materials on the one hand, and the academic level already attained by the students. The student may feel that studying the material is a waste of time because the content has been studied as part of their specialized subject or the teacher is not confident due to his inadequate or insufficient knowledge (p.101).

Crocker (1981) looks at the role of ESP teacher from methodological point of view. He suggests that objectives of learning should be negotiated between the subject and language specialists. In this respect, the final decision regarding learning objectives should be taken by the subject specialist and that learning objectives regarding methodology and resources necessary to achieve the objectives should be taken by the ESP teacher (p.9). Crocker's suggestion seems to be a reasonably good answer to the problem raised by Abbot (1978) who questions whether it is the ESP teacher's responsibility to deal with content (p.103). Crocker also says that, "The role of the practicing LSP teacher is not that of an academic whose interest is in a body of information, but that of a professional offering a practical service" (p.9). This implies that an ESP teacher is someone who facilitates learning, not someone who provides information or content. The role of a facilitator would also free the teacher from having to write materials. In this regard, Crocker (1981) also says that, "if the LSP teacher's role is predominantly that of information, there is pressure to become familiar with a range of other subject disciplines and ....to materials preparation" (p.13). Being a facilitator, an ESP teacher has to have sufficient knowledge and skills of classroom management; that is the ability to work with the students to arrive at the desired goals of learning.

Early (1981) states that ESP teachers cannot be expected to possess knowledge of subject matter in depth although his or her knowledge about the language is adequate. This condition may cause the teacher to have insecure feeling (Abbot 1976) related to his or her social status as a teacher. As an alternative, according to Early, may be to develop a collaborative, team-teaching with the subject teacher. However, this collaborative effort would be expensive in terms of time and money and raise practical difficulties due to the inherent dissimilarities between English and subject disciplines. Adams-Smith (1980), as quoted in Early, says that,

" there are obvious massive difficulties in the way of establishing real team- teaching between disciplines as dissimilar as English and Biochemistry or $\mathrm{Me}$ chanical Engineering, among them being near total mutual incomprehension of purpose, subject matter, and pedagogical approach, together with conflicting schedules, different commitments to research and problems of basic attitude" (p.46).

Instead of designing collaborative programs, Early (1981) suggests what may be called "interactive" method by which the teacher and the student can communicate genuinely on an individual basis or small group on topics of interest. With this method, Early says, "the language teacher's role will recede in proportion to the emergence of significant content in communication" (p.48).

Holliday (1994) observes that many English teachers in the countries where English is a foreign language (EFL context) find the communicative methodology a "failure". In EFL contexts, English is taught as part of the wider (national) curriculum and the teaching of English is constrained by educational and institutional factors such as time availability, budgeting, facilities, teacher's qualifications, etc. English teachers who want to apply communicative methodology frequently (almost always) have to reconcile their teaching style with the expectations from other subject teachers, especially when language activities are carried out in group or pair work. Students also have different expectations carried over from other subjects which are often teacher-centered, a learning experience which does not conform to that commonly found in communicative classrooms.

Part of the "failure" of the communicative methodology is also due to teachers' misconceptions of the communicative teaching. They perceive Communicative Language Teaching (CLT) as a methodology with the emphasis only on oral communication. Considering the constraints of teaching in an EFL context such as large classes, it is unlikely that the teaching will achieve its desired objectives. Holliday (1944) suggests that the idea of CLT has to be re-interpreted to suit it to the EFL context. He says,

"...the communicative approach should not be narrow at all, but essentially adaptable to all requirements of the classroom situation within its wider institutional and social setting. "Communicative" does not therefore mean having students practicing communication in pairs or groups. It means making decisions appropriate to the educational environment, about whether or not, or how often to have pair or group work, and about the lesson's focus - on speaking, reading, writing, grammar, pronunciation, etc., none of which need be precluded in a communicative approach" (p.7) 
Holliday argues that teachers are the key to what happens in the classroom. They must find the best way of teaching that are suitable to their classroom and do not entirely rely on techniques developed in the countries where English is the first or second language (p.9). Therefore, designing an ESP program requires a careful needs-analysis not only of the students themselves but also of the institution where the program is being planned as well as any aspect pertaining to language.

\section{NEEDS ANALYSIS, THEORETICAL BASIS AND APPROACHES}

Definition of needs vary depending on the purpose of analysis but all take the learner as a focus of analysis. Lawson (1979) defines "need" as "something that is recognized but it is not in any sense "discovered", and its "existance" derives from whatever criteria are thought to be relevant in making the diagnoses" (p.37). This implies that in order to recognize "needs" one would have to carry out some kind of assessment or evaluation of the existing situation and the diagnosis of assessment results would reveal some deficiency.

Widdowson (1981) differentiates "goal-oriented" definition from "process-oriented" definition of needs. The former refers to what the learner needs to do with the language once he or she has learned it, while the latter refers to what the learner needs to do to actually acquire the language (p.2). This definition points to the importance of recognizing the present condition of the learner as far as language learning is concerned, and the target situation where the learner will be required to use the language. The "goal-oriented" definition has to do with program aims while the "process-oriented" definition relates to pedagogic objectives (Widdowson, 1983:20).

Hutchinson and Waters (1987) make a distinction between "target needs" and "learning needs". The target need refers to what the learner needs to do in the target situation and the learning need refers to what the learner needs to do in order to learn (p.54). They further subcategorize target need into (1) necessities; what the learner has to know in order to function effectively in the target situation, (2) lacks; the discrepancy between necessity and what the learner already knows, (3) wants; what the learner actually wants to learn or what they feel they need. The learner's "wants" may or may not conform those perceived by the teachers or course designers (pp.55-57). The learning need is equated to the route of learning.
This concerns things such as how learners learn the language, why they learn it what resources are available to help them learn (pp.62-63).

Berwick (1989), borrowing some insights from the field of adult education, defines "need" as "the gap between what is and what should be" (p.65). The "what is" could be equated to the current state of learner's knowledge and skills and the "what should be" could be interpreted as the target situation requirements. Robinson (1991) notes that the needs that are established for a particular group of students... will be influenced by the ideological preconceptions of the analyst. A different group of analysts working with the same group of students but with different views on teaching and learning would be highly likely to produce a different set of needs (p.7).

Types of needs are differentiated with reference to the purpose of learning the language, individual differences or the social roles of language in a wider context. Alderson (1980) differentiates four types of needs. First, formal needs which refer to the need to meet the institution requirements such as to pass an exam. Second, actual or obligation need which refers to what a student has to do with the language once he has learned it. Third, hypothetical future need which refers to the need to become a better professional in the future, and forth, want, which refers to what a student feels want to do or to learn. The first and the forth are types of needs during the process of learning or "process-oriented" type, while the second and third are types of needs that are "future-oriented".

Altman (1980) explains types of learner needs based on individual differences within the framework of learner-centered language teaching. According to Altman (1980), learners should be placed properly based on their age, level of language proficiency, maturity, time available. This requires the institution to make flexible educational arrangements to allow all learners access to learning that is appropriate to the types of needs they have. In this way, the content and mode of learning will be influenced by the options available at their disposal. The types of modifications of learning resources are made accordingly to meet the kinds of individual differences with regard to time, goals, mode, or expectations of learning (p.9). Berwick (1989) makes a distinction between felt needs or expressed needs; needs that learners have, and perceived needs; judgment about the educational gaps in other people's experience (p.5).

Brindley (1989) identifies two types of needs. First, objective need, which is derivable from factual information about the learner, use of language in daily 
communication, current language proficiency and language difficulties. Second, subjective need, referring to cognitive and affective needs in learning such as personality, confidence, atitude, wants and expectations in learning. Brindley states that while objective needs are accessible through data collection such as tests, identifying subjective needs is difficult because of the "elusive nature of the variables" (p.70)

Kharma (1980) discusses societal needs and educational needs. The societal need refers to the need of the community as a whole to acquire and use English for international communication, for trade, technology, cultural purposes etc. The educational need is the need of an individual to use English in the community. In an EFL setting, this need can be differentiated into general and specific educational needs. The first is related to the cultural, intellectual and affective development of the individual learner. The second is related to specific skills that learners are expected to master such as listening, speaking, reading or writing, or to skill which can be described in terms of language functions (pp.51-53).

\section{THEORETICAL BASIS OF NEEDS ANALYSIS}

Much of the literature that is used as bases of needs analysis is derived from the views of communicative competence. Hymes's (1972) discussion on communicative competence theory covers two aspects; linguistic competence, that is the unconscious knowledge of the language, and linguistic performance, that is the use of language associated with the process of encoding and decoding. Language use is judged not only by grammaticality but also by other aspects such as appropriateness. As Hymes puts it, "There are rules of use without which the rules of grammar would be useless" (p.278). Language use and meaning of utterances also involves aspects that cannot always be explained with reference to formal aspects of language. Grammaticality or structurally similar sentences may be interpreted as a statement, a command, or a request. Or, two sentences with different structures may be understood as the same speech act.

Hymes (1972) mentions four criteria by which communicative competence can be evaluated.

1. Whether something is formally possible. It relates to grammaticality.

2. Whether something is feasible. It relates to psychological acceptability.
3. Whether something is appropriate. It relates to socio-cultural acceptability. 4. Whether something is in fact done, or the speech act is actually performed.

Competence-performance distinction is also extensively discussed in Canale and Swain (1980) as bases for language teaching and testing applications. They refer to Chomsky's weak version of competence as knowledge of grammar and other aspects of language while performance is concerned with social aspects of language while performance of the language such as acceptability.

Another aspect of the theory of communicative competence is drawn from the work of van Ek's "Threshold Level" (1976) which Canale and Swain call "basic communication skills". Van Ek's work describes the minimum level of communication skills needed by learners for survival purposes in a second or foreign language setting. Van Ek's model provides a list of basic language functions and notions that are important for the learner. Canale and Swain suggest that basic communication skills discussed in van Ek's "Threshold Level" can be considered as a minimum level of communication skills and in language learning these skills should be emphasized from the beginning in order to provide learners with the ability to get meaning across. However, they caution that second language learners may or may not be willing only to develop skills to get meaning across without studying aspects of grammar. Drawing conclusions from studies on second language learning, they state that "the focus on grammatical competence in the classroom is not a sufficient condition for the development of communicative competence. However, it would be inappropriate to conclude that the development of grammatical competence is irrelevant or unnecessary for the development of communicative competence" (p.13). This statement implies that it is reasonable to take the middle way; that is to combine both approaches in instruction where grammatical aspects of the language are incorporated into meaningful communicative practice.

Another theory proposed by Canale and.Swain (1980) is to integrate the theories of grammaticality and acceptability on the one hand, to the theory of discourse. In their view, "an integrative theory of communicative competence may be regarded as one in which there is a synthesis of knowledge of basic grammatical principles, knowledge of how language is used in social context to perform communicative functions, and knowledge of how utterances and communicative functions can be combined according to the principles of discourse" ( $p 20$ ). This integrative theory of communicative competence is more comprehensive in that it 
also covers theory of coherence, cohesion, conversational analysis, and speech acts. (more references are needed!).

\section{APPROACHES TO NEEDS ANALYSIS}

Several approaches to needs analysis have been proposed. Benesch (1996) develops a "critical approach" to needs analysis in the area of writing skill for ESL students in which students are trained to develop their skills to evaluate topics through writing assignments. Her writing course was paired with a psychology class and she considered this class as the target situation because it was the students' major. The assignments for the students were taken from topics discussed in the psychology lectures. Among others, students were assigned either individually or in small groups to review lecture notes, write questions about the psychology lectures for class discussions, rewrite questions for meaning and revision, write research papers on a particular topic discussed in the psychology class.

Cunningsworh (1983) uses van Ek's "Threshold Level" as bases for needs analysis. The specifications of learners' target needs are designed to equip learners to "maintain themselves in most everyday situations, including situations for which they have not been specifically trained" (in van Ek, 1975). Although specifications of needs cover those situations that adequately serve learner needs at this level, Cunningsworth (1983) comments that they are based on intuition and subjective judgment and that this subjectivity would, in turn, influence the syllabus designer to rely on his subjective judgment.

Holec (1980) proposes "self-directed learning" approach to learner needs. This approach is based on the principle that "to teach the learner to learn is to enable him to carry out the various steps which make up the learning process. This "autonomy" of the learner enables appropriate solutions to be found for the problems of differences in the needs... thus, narrowing considerably the gap between what the learner wants to learn and what he does in fact learn" (p.31). Under this approach the learner has the "autonomy" to determine the level of knowledge he wants to achieve, the communicative behavior he believes he will need, the level of competence he wishes to reach, or the objectives he wants to accomplish.

Holliday (1995) proposes an ethnographic approach to needs analysis. It involves institutional factors in the process of needs analysis. Needs analysis as a basis of curriculum design will be realistic if there are means for implementing it. In this case, the institution where the analysis is carried out, and the administration staff need to provide supports, access, and resources that are necessary for implementation, such as access to study documents, interviews or visits to offices.

The Munby needs analysis approach is adequately summarized in Hawkey (1980). Munby's analysis is a tool for syllabus design which provides a detailed profile of learners and what they need to be able to do after the course or what they need to study during the course. In addition, the analysis also provides a specification of language skills, functions and forms that are required in order to carry out communication types as described in the needs profile.

In Munby's model, the needs profile comprises answers to questions such as:

Who are the learners?

Which study or occupational area will they need English for?

Where and when will they need to use English, with whom?

Handling which media and modes?

Handling which dialects of English?

At what level?

To participate in which communicative activities?

In what tone?

Answers to these questions form the "communication needs profile". of the learner which is, then, used as bases for selection of language skills, functions, and forms. In the analysis there are eight parameters used to label the learner's needs: purposive domain, setting, interaction, instrumentality, dialect, target level, communicative event, and communicative key.

Richterich and Chancerel (1980) proposes a "systemic approach" to needs analysis. This work was done as part of the project for Council of Europe. As the name suggests, the analysis involves administrators who are involved in teaching, teachers and learners - all parties that are involved in language learning. This approach places the learner as the center of the system and decisions concerning objectives, assessment and curriculum are designed with reference to the learner's resources. The information for needs analysis is collected from the learner, the teaching institution, the user-institution and society. 
Altman (1980) proposes "learner-centered approach" to analyze the learner needs in language teaching. He recognizes that learners have individual characteristics and differences and that the differences should be addressed accordingly through appropriate instructions. In the learning process, the instruction is designed in such a way to meet individual needs and to allow each individual to develop his or her potentials. The learner needs, abilities and interests determine the form and design of the language curriculum. This learner-centered language teaching is based on the premise that every learner is uniquely different and that all learners do not learn a foreign language equally well with the same pace. Therefore, learning materials, mode of learning and time allocations are adapted to suit different individual preferences. Altman (1980) provides a table which accommodates learners differences with eight different patterns of learning arrangements and modifications to meet individual learning needs.

\section{WHY NEEDS ANALYSIS IS IMPORTANT AND INSTRUMENTS FOR NEEDS ANALYSIS}

The discussions of the importance of needs analysis focus on its roles as a starting point or a guide for course design, syllabus design, materials selection, assessment or even classroom activities. Berwick (1989) says that needs assessment is important for decision planners to design the course. Assessment of a course needs involvement of learners

Changes concerning learner needs may have to be made during the course with consultation of the learners.

Hawkey (1980) says that needs analysis is a tool for course designer. This presupposes a "language training situation with reasonably specific occupational or educational objectives involving a reasonably homogeneous group of learners" or educational objectives involving a reasonably homogeneous group of able to produce a specification of language skills, functions, and forms as required in the learner needs profile.

McDonough (1984) states that the language needs of the learner should be the bases for course development. He says, "information on his or her language needs will help in drawing up a profile to establish coherent objectives, and take subsequent decisions on course content " (p.29).
Riddell (1991) points to the crucial role that needs analysis plays in syllabus and course design. As he puts it, “...through it [needs analysis] the course designer becomes equipped to match up the content of the program with the requirements of the student body [what learners need]" (p.75). With reference to the third world context, he considers teaching materials as an important factor. Teachers can use published materials, adapt or write in house materials. Whatever option is taken, the assessment of student needs has to be taken into consideration (p.75).

Bowers (1980) notes the importance of needs as a guide in syllabus development, materials and examination. The importance of needs is quoted in Clark (1978), who says that, "The first step in any language teaching project must surely be to design a syllabus that will reflect the language needs and wishes of the learner concerned, and that will accord with a responsible theory of language learning" (p.67 in Bowers). According to Jordan (1997), needs analysis should be the starting point for devising syllabus, course materials and classroom activities (p.22). In Shutz and Derwing (1981), needs analysis is considered as the first step that any course planner should take. They quote Palmer and McKay (1978:3) who say that,

"Many well-intentioned language programs ... have foundered because either no consideration was given to the actual use the learner intended to make of the language or because the list of uses drawn up by the course designer was based on imagination rather than an objective assessment of the learner's situation, and proved to be inaccurate and in many cases entirely inappropriate to his real needs" (p.30 in Schutz and Derwing).

Recognizing that language problems can also be traced through sociological context, Schutz and Derwing agree that, "...a detailed analysis of the situations of language use is a pre-requisite even to the selection of the particular linguistic forms or structures that ought to be taught" (p.31).

Brindley (1980) argues that objective needs should be used as a starting point in course design. He says, "If instruction is to be centered on the learners and relevant to their purposes, then information about their current and desired interaction patterns and their perceived difficulties is clearly helpful in establishing program goals which in turn can be translated into learning objectives" (p.64). He further states that needs analysis is essential in two different ways; (1) as a guide in setting broad goals, and (2) as a guide in 
the learning process. The importance of needs is also recognized in the learnercentered language teaching. In this system, the learner and the teacher need to continuously share information as to what the learner wants or needs to study during the course. Needs analysis should be carried out throughout the course in order to adjust the learning objectives as the need arises. In other words, feedback from the learner can be used as bases for modifying learning objectives. Savage and Storer (1992) discusses the role that learners can have in the process of needs assessment. Learners can contribute substantially to the course if they are actively involved at all stages of the course design; at the initial, during, and final stages of course evaluation.

Questionnaires and interviews are two commonly used instruments for needs andilysis. Christison and Krahnke (1986) believe that students' own experience can be used as a basis for planning teaching program and curriculum design. They observe that much of what is taught is based on the teacher's beliefs rather than facts (p.63). Christison and Krahnke use structured questionnaire to find out the students' language learning experience during the program. The questionnaire covers language skills area, out-of-class language experience, aspects of the language program and opinions about their language teachers.

Clowes (1994) analyzes language needs of industry. He interviewed people working in the industry to find out their perception of needs (what is the need and what are the reasons for it) and language use (which people in business will be using languages and for what purposes).

Howell's (1995) study on students' needs and expectations of Chinese language learning reveals some interesting results. His study uses questionnaire and interview techniques to find out what the students need during the program, what aspects of the program that need improvements and views on how well the program prepares the students to enter business or employment in general. He assumes that "students' views can provide valuable information for reviewing of developing effective strategies for learning and teaching ..." (p.22).

Jordan (1993) studies language learning difficulties experienced by overseas students in Britain. He uses questionnaire which covers students' language learning experience in their own countries, expectations during the language course in Britain and difficulties they experience during the course. Schutz and Derwing (1981) use questionnaire to find out students' characteristics, previous English language learning experience, motivations, attitudes and relevance of the program to future job.
The approaches to needs analysis and the ideas discussed int the previous sections can be used as the basis to form a model as a framework for an ESP syllabus design. The model is presented below.

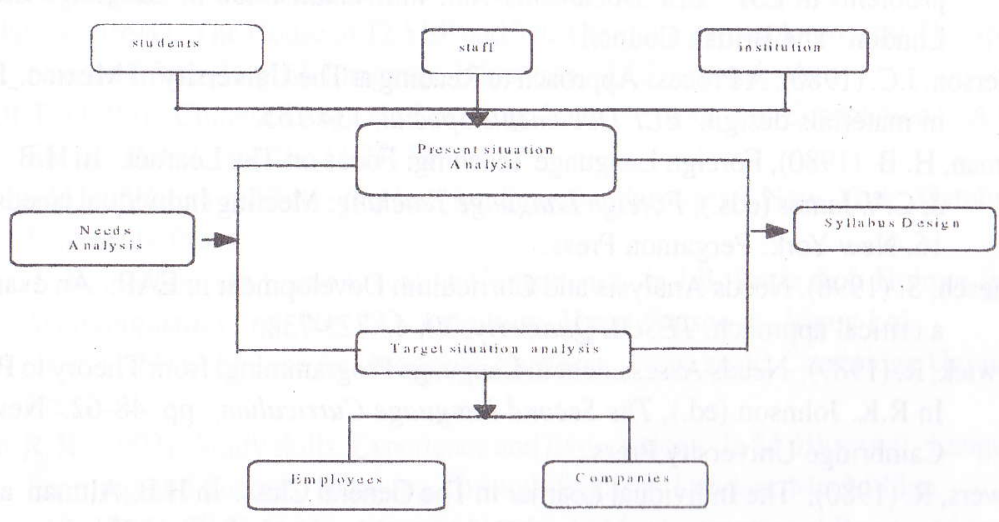

The present situation analysis is an analysis of the present condition of teaching and learning situation covering aspects related to students' characteris tics, staffing, materials, syllabus and academic records containing data about students' language learning. The target situation analysis is an analysis of the workplace where the students will work or use the language. This will produce an analysis of language use, functions and types of activities or events which involve the use of English. The results of both analyses can be used as bases for English language syllabus design. As can be seen in the figure, needs-analysis is the starting point in the process of syllabus design in ESP. Although 'needs' are defined differently and the types of needs as well as its approaches vary, the purposes of needs-analysis is to form a basis on which a language syllabus can be designed.

\section{CONCLUSION}

Needs-analysis should be seen as an indispensable aspect of ESP syllabus design in order to link the present students' academic needs with their needs in their prospective employment. Needs-analysis involves not only the students but also all parties in the educational system and relevant user institutions that ultimately employ students. The literature in this field abounds with models and approaches of needs-analysis and they should be reviewed and selected on the basis of contexts and conditions of teaching and learning in Indonesia. 


\section{REFERENCES}

Abbot, G. (1978), Motivation, Materials, Manpower and Methods: Some Fundamental problems in ESP. ELT Documents 103: Individualisation in Language Learning London: The British Council

Alderson, J.C. (1980), A Process Approach to Reading at The University of Mexico,_Projects in materials design. ELT Documents Special, 134-163.

Altman. H. B. (1980), Foreign Language Teaching: Focus on The Learner. In H.B. Altman \& C.V. James (eds.), Foreign Language Teaching: Meeting Individual Needs, pp. 1 16. New York: Pergamon Press.

Benesch, S. (1996), Needs Analysis and Curriculum Development in EAP: An example of a critical approach. TESOL Quarterly, 30, 4, 723-738.

Berwick, $\mathcal{K}$. (1989), Needis Assessment in Language Programininiz: from Theory to Practice. In R.K. Johnson (ed.), The Second Language Curriculum, pp. 48-62. New York: Cambridge University Press.

Bowers, R. (1980), The Individual Learner in The General Class. In H.B. Altman adn C.V. James (eds.), Foreign Language Teaching: Meeting Individual Needs, pp. 66-80. New York: Pergamon Press.

Brindley, G. (1989), The Role of Needs Analysis in Adult ESL Programme Design. In R.K Johnson (ed), The Second Language Curriculum, pp, 63-78. New York: Cambridge University Press.

Canale \& Swain (1980), Theoretical Bases of Communicative Approaches to Second Language Teaching and Testing. Applied Linguistics, 1, 1

Christinson, M.A. \& Krahnke, K.J. (1986), Student Perception of Academic Language Study, TESOL Quarterly, 20, 1, 61-79.

Clowes, P. (1994), Learning What are The Language Needs of Industry? Language Journal. 9. $22-25$.

Crocker, T. (1981), Scenes of Endless Science: ESP and Education. The ESP Teacher: Role, Development and Prospects. ELT Documents 112, 7-15. London: The British Council.

Cunningsworth, A. (1983), Needs Analysis - A Review of The State of The Art. System, II 2. $149-154$.

Early, PB (1981), The ESP Teacher's Role: Implications for The Knower-Client Relationship. The ESP Teacher: Role, Development and Prospects. ELT Documents. London: The British Council.

Hawkey, R. (1980), Syllabus Design for Specific Purposes. ELT Documents Special. Projects in Materials Design. London: The British Council

Holec, H. (1980), Learner Training: Meeting Needs in Self-Directed Learning. In H.B.
Altman \& C.V. James (eds.) Foreign Language Teaching: Meeting Individual Needs pp. 30-45. New York: Pergamon Press.

Holliday, A. (1995), Assessing Language Needs within An Institutional Context: An Ethnographic Approach. English for Specific Purposes, 14, 2, 115-126.

Holliday, A. (1994), The House of TESEP and The Communicative Approach: The Special Needs of State English Language Education. ELT Journal, 48, 1.

Howell, F. (1995), Chinese Language Learning: Student Needs and Expectations: A Case Study, Babel, 30, 2, 22-27, 33

Hutchinson \& Waters (1987), English for Specific Purposes. New York: Cambridge University Press.

Hymes, D.H. (1972), On Communicative Competence. In J.B. Pride \& J. Holmes (eds.), Sociolinguistics, pp. 269-293. Aylesbury: Hazel Watson \& Viney Ltd.

Jordan, R.R. (1997), English for Academic Purposes. New York: Cambridge University Press.

Jordan, R. R. (1993), Study skills: Experience and Expectations. In M. Blue (ed), Language, Learning and Success: Studying Through English. London: MacMillian.

Kharma, N. (1988), ELF and Community Needs. IRAL: International Review of Applied Linguistics, XXXVI, 1, 49-67.

Lawson, K.H. (1979), Philosophical Concepts and Values in Adult Education. Milton: Open University Press

McDonough, J. (1984), ESP in Perspective: A Practical Guide. London: Jo McDonough

Richterich, R. \& Chancerel, J.L. (1980), Identifying the Needs of Adults Learning a Foreign Language. New York: Council of Europe.

Riddcll, P.G. (1991), Analyzing Student Needs in Designing Specific Purposes Language Syllabuses. Language Learning Journal, 3, 73-77.

Robinson, P. (1991), ESP Today. New York: Cambridge University Press.

Savage \& Storer (1992), An Emergent Language Program Framework: Actively Involving Learners in Needs Analysis. System, 20, 2, 187-199.

Schutz \& Derwing (1981), The Problems of Needs Assessment in English for Specific Proposes: Some Theoretical and Practical Considerations, In R. Mackay and J.D. Palmer (eds.), Languages for Specific Purposes, Program Design and Evaluation. pp. 29-44. London: Newbury House.

Swales, J. (1980), The Educational Environment and Its Relevance to ESP Programme Design, pp. 61-70. ELT Documents Special. London: The British Council

Widdowson, H.G. (1981), English for Specific Purposes: Criteria for Course Design. In L. Selinker et al. (eds.), English for Academic and Technical Purposes: Studies in Honor of Louid Trimble, pp. 1-11. London: Newbury House.

Widdowson, H.G. (1983), Learning Purpose and Language Use. New York: Oxford University Press. 